\title{
EVALUATION OF SUSTAINABLE DEVELOPMENT OF ENTERPRISES IN THE DIGITAL TRANSFORMATIONS
}

\author{
Maryna Demianchuk ${ }^{1,2}, *$ Valerijs Skribans ${ }^{3}$ \\ ${ }^{1}$ Odessa I.I. Mechnikov National University, Ukraine \\ ${ }^{2}$ Institute of Market Problems and Economic-Ecological Research of the Academy of Sciences of Ukraine, \\ Ukraine \\ ${ }^{3}$ Riga Technical University, Latvia \\ *Corresponding author's email: valerijs.skribans@rtu.lv
}

\begin{abstract}
In the context of digital transformations, the development of telecommunications enterprises is one of the basic conditions for the digitalization of the country's economy. The paper developed a mechanism for assessing the effectiveness of sustainable development of a telecommunications enterprise, based on the principles of constructing neural networks by assessing the economic, environmental and social subsystems of the enterprise. The mechanism is a set of analytical, evaluative and resulting blocks, the key link of which is to determine the multiplier of the effectiveness of balanced development based on the calculation of indicators of economic, social, environmental and institutional subsystems of external and internal development in order to form a triune strategy for concretizing potential opportunities in the context of digital transformations and its application as a correction factor in assessing the business value of a telecommunications company.
\end{abstract}

Key words: balanced development, telecommunication enterprise, digital transformation, efficiency, multiplier.

\section{Introduction}

Nowadays, there is a significant amount of scientific research on the organization and development of the information and communication technologies (ICT) market. In the monograph (Steklov, Kostik, \& Berkman, 2005) the principles of building modern control systems in telecommunications are considered, the presented modern control systems are implemented and the economic efficiency from its implementation is assessed. In scientific works (Vorobienko \& Granaturov, 2011; Granaturov, 2009; Granaturov \& Vorobienko, 2009), the problems of using the patterns of ICT influence on the economic development of the country have been identified and methodological and methodological tools have been developed for analyzing the competitiveness of telecommunications services. The impact of information and communication technologies (Iscan, 2012), as well as broadband internet on the economy and economic growth of the country is considered (Katz, 2012). A study of rural communities in India, Mozambique and Tanzania (Souter et al., 2005) was conducted to identify the economic impact of telecommunications on agriculture and poverty reduction. The development of information and telecommunication technologies in the "ICT for development value chain" is considered based on indicators of vulnerability and accessibility of ICT (Heeks, 2010); the impact of the American wireless telecommunications industry on the US economy (Entner \& Lewin, 2010). The components of ensuring effective regulation of the modern services market (Orlov et al., 2011), the process of information assets of enterprises in the field of telecommunications (Redkin \& Koval, 2007), market mechanisms and structures of the economy of information and communication services (Striy, Zaharchenko, \& Golubev, 2014) have been analyzed, shows the importance of marketing strategies in the field of telecommunications (Khrushch \& Koran, 2011); substantiated the need to reorient telecommunications companies to a new sustainable type of development (Kniazieva \& Doysan-Korovenkova, 2015; Kniazieva \& Kalugina, 2015), as well as the factors that necessitate the transition of a telecommunications company to new forms of marketing communication channels and provide the main types of effect that can be obtained (Maslii et al., 2017; Demianchuk et al., 2021). At the same time, the analysis of scientific literature made it possible to reveal that among the numerous scientific works in the context of digital transformations, special attention should be paid to the development of a mechanism for evaluating the effectiveness of the balanced development of telecommunications enterprises, which is the purpose of the work.

\section{Materials and Methods}

The conceptual and methodological basis of the work is formed by scientists specializing in the theory and practice of sustainable development of enterprises. The study is based on a set of general scientific and special methods of cognition of the theoretical, methodological and conceptual foundations of the balanced development of a telecommunications enterprise, in particular, for developing a mechanism for evaluating the effectiveness of balanced development of telecommunications enterprises, process and synergetic approaches with elements of neural network modeling, methods of optimization, formalization, factor analysis and simulation were used. 


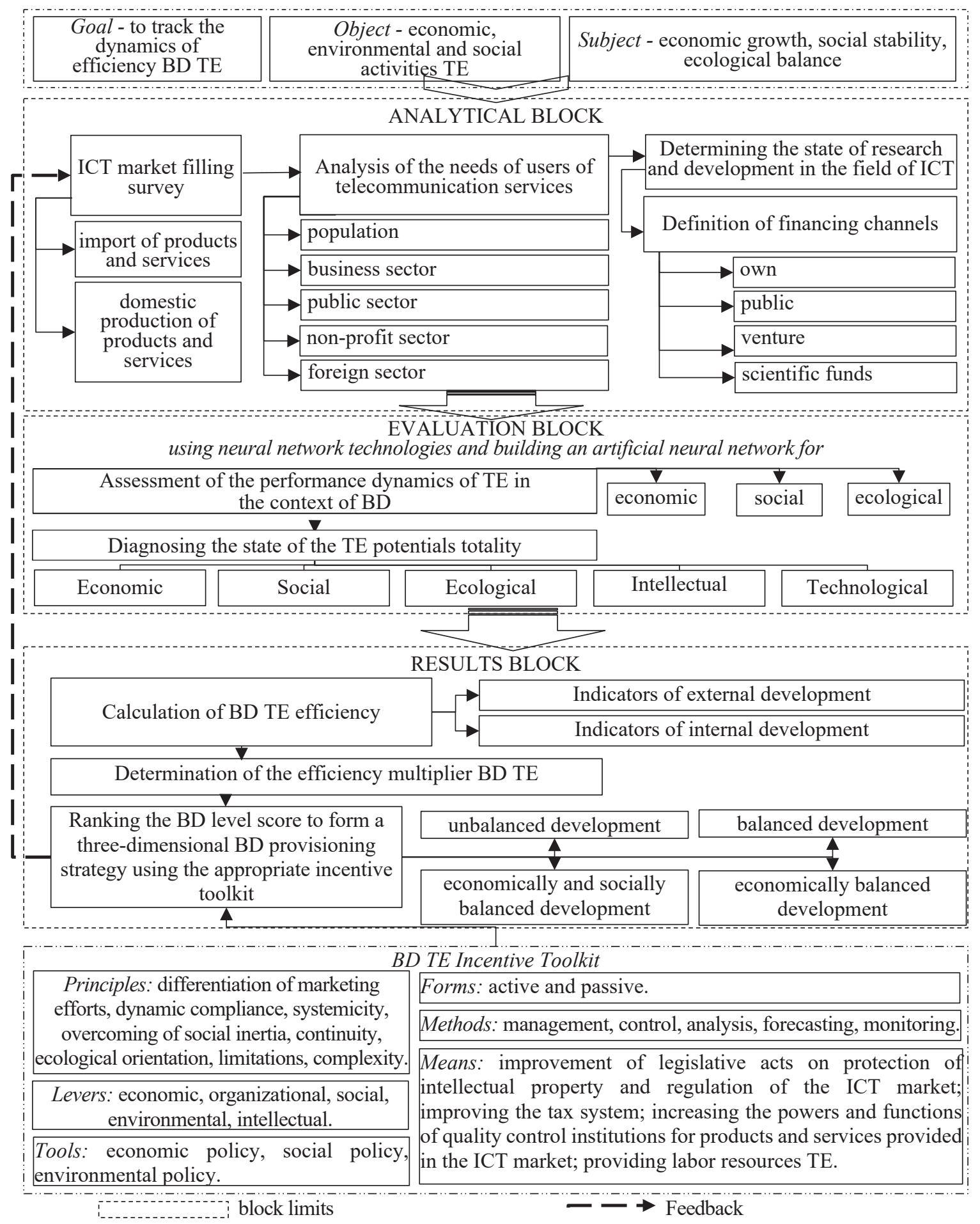

Figure 1. Efficiency evaluation mechanism balanced development of a telecommunications enterprise. Source: constructed by the authors.

\section{Results and Discussion}

In the research, developed efficiency evaluation mechanism of balanced development of a telecommunications enterprise is shown in Figure 1. The main purpose of the mechanism is to track the dynamics of the effectiveness of a balanced development $(\mathrm{BD})$ of a telecommunications enterprise (TE) (BD TE).

The developed mechanism consists of three blocks: analytical, evaluative and resulting. The first analytical block is responsible, firstly, for the survey of the content of the ICT market with the determination 
Indicators of internal balanced development of a telecommunications enterprise

Table 1

\begin{tabular}{|c|c|c|}
\hline № & Name and essence of indicators & $\begin{array}{l}\text { Calculation } \\
\text { formula }\end{array}$ \\
\hline 1.1. & \multicolumn{2}{|l|}{$\begin{array}{l}\text { Indicators of the economic subsystem are based on funds }\left(\mathrm{C}_{\mathrm{e}}^{\prime}\right) \text { that were spent on measures for economic } \\
\text { development }\end{array}$} \\
\hline 1.1.1. & $\begin{array}{l}\text { The financial stability shows the change in the financial condition of a telecommunications } \\
\text { company }\left(\Delta \mathrm{K}_{\mathrm{fs}}\right)\end{array}$ & $D_{1.1}^{\prime}=\frac{\Delta K_{f s}}{C_{e}^{\prime}}$ \\
\hline 1.1 .2 & $\begin{array}{l}\text { The activity profitable dynamics shows the change in the profitability of the economic activity of a } \\
\text { telecommunications enterprise }\left(\Delta \mathrm{K}_{\mathrm{r}}\right)\end{array}$ & $D_{1.2}^{\prime}=\frac{\Delta K_{r}}{C_{e}^{\prime}}$ \\
\hline 1.1.3. & $\begin{array}{l}\text { The equality of the tax burden of the enterprise's activities to the measures of the economic } \\
\text { development of the enterprise is calculated as the change in the tax burden }\left(\Delta \mathrm{K}_{\mathrm{t}}\right)\end{array}$ & $D_{1.3}^{\prime}=\frac{\Delta K_{t}}{C_{e}^{\prime}}$ \\
\hline 1.2 . & \multicolumn{2}{|l|}{$\begin{array}{l}\text { The indicators of the social subsystem take into account intellectuality and digital sufficiency of the } \\
\text { employees of the enterprise, as well as the complexity of their social support, taking into account the funds } \\
\left(\mathrm{C}_{\mathrm{s}}^{\prime}\right) \text { that were spent on social development activities }\end{array}$} \\
\hline 1.2 .1 & $\begin{array}{l}\text { The intellectuality of the staff of a telecommunications enterprise provides a dynamic change in the } \\
\text { level of intellectuality of enterprise }\left(\Delta \mathrm{K}_{\mathrm{i}}\right)\end{array}$ & $D_{2.1}^{\prime}=\frac{\Delta K_{i}}{C_{s}^{\prime}}$ \\
\hline 1.2.2. & employees of a telecommunications enterprise $\left(\Delta \mathrm{K}_{\mathrm{d}}\right)$ & $D_{2.2}^{\prime}=\frac{\Delta K_{d}}{C_{s}^{\prime}}$ \\
\hline 1.2.3. & social infrastructure to meet the social, domestic and cultural needs of employees $\left(\Delta \mathrm{K}_{\mathrm{s}}\right)$ & $D_{2.3}^{\prime}=\frac{\Delta K_{s}}{C_{s}^{\prime}}$ \\
\hline 1.3 . & \multicolumn{2}{|l|}{$\begin{array}{l}\text { The indicators of the ecological subsystem reflect the energy efficiency, the safety of work, the pollution track of the } \\
\text { enterprise, taking into account funds }\left(\mathrm{C}_{\mathrm{ec}}^{\prime}\right) \text { that were spent on environmental development measures }\end{array}$} \\
\hline 1.3.1. & $\begin{array}{l}\text { Energy efficiency reveals improvements in the consumption of energy resources in the activities of a } \\
\text { telecommunications enterprise }\left(\Delta \mathrm{K}_{\mathrm{e}}\right)\end{array}$ & $D_{3.1}^{\prime}=\frac{\Delta K_{e}}{C_{e c}^{\prime}}$ \\
\hline 1.3 .2 & $\begin{array}{l}\text { The safety of work is calculated as a change in the working conditions of employees of a } \\
\text { telecommunications company }\left(\Delta \mathrm{K}_{\mathrm{w}}\right)\end{array}$ & $D_{3.2}^{\prime}=\frac{\Delta K_{w}}{C_{e c}^{\prime}}$ \\
\hline 1.3 .3 & The pollution track of operation shows the change in the level of emissions $\left(\Delta \mathrm{K}_{\mathrm{h}}\right)$ & $D_{3.3}^{\prime}=\frac{\Delta K_{h}}{C_{e c}^{\prime}}$ \\
\hline 1.4 . & \multicolumn{2}{|c|}{$\begin{array}{l}\text { The indicators of the institutional subsystem expose the concentration of the system, the coherence of } \\
\text { management actions and the sensitivity of the quality of the services provided, taking into account the funds } \\
\left(\mathrm{C}^{\prime}{ }_{\mathrm{in}}\right) \text { that were spent on measures for the institutional development of the enterprise }\end{array}$} \\
\hline 1.4 .1 & $\begin{array}{l}\text { The concentration of the system demonstrates the effectiveness of the existing organizational } \\
\text { structure }\left(\Delta \mathrm{K}_{\mathrm{o}}\right) \text { with the changes over time }\end{array}$ & $D_{4.1}^{\prime}=\frac{\Delta K_{o}}{C_{i n}^{\prime}}$ \\
\hline 1.4.2. & $\begin{array}{l}\text { The consistency of management actions expresses the change in the effectiveness of the } \\
\text { management actions taken to develop the activities of an enterprise }\left(\Delta \mathrm{K}_{\mathrm{c}}\right)\end{array}$ & $D_{4.2}^{\prime}=\frac{\Delta K_{c}}{C_{i n}^{\prime}}$ \\
\hline 1.4.3. & $\begin{array}{l}\text { The sensitivity of the quality of telecommunications services is calculated as the ratio of the } \\
\text { difference in the quality of services }\left(\Delta \mathrm{K}_{\mathrm{q}}\right) \text { in the current and previous periods }\end{array}$ & $D_{4.3}^{\prime}=\frac{\Delta K_{q}}{C_{i n}^{\prime}}$ \\
\hline
\end{tabular}

Source: constructed by the authors.

of the volume of domestic production of goods and services and imported ones. Secondly, the needs of users of telecommunications services, highlighting such segments as the population, business, government non-profit and foreign sectors are analyzed. This segmentation of telecommunications consumers will allow the most detailed study of needs, determine the demand for existing services and establish the potential demand for innovative products and services. It will also allow for measures to stimulate or create demand for these products and services. Thirdly, clarification of researches in the field of ICT makes it possible to assess developments in order to understand the needs and potential demand of consumers of telecommunications services. At the same time, it is also advisable to determine the financing channels (state, venture, scientific funds) in order to establish the level of commercialization of 
research and find out amounts of financial resources for the plans implementation.

The second evaluation block evaluates the dynamics of the effectiveness of the economic, social and environmental activities of a telecommunications enterprise, as well as diagnosing the state of the totality of its economic, social, environmental, intellectual and technological potential. It is advisable to carry out the assessment and diagnosis processes using neural technologies and building an artificial neural network (Demianchuk, 2020).

The third resulting block is aimed at calculating the efficiency of the BD TE based on indicators of internal and external development, ranking the assessment of the BD TE level based on determining the TE efficiency multiplier in order to use it as a

Indicators of external balanced development of a telecommunications enterprise

\begin{tabular}{|c|c|c|}
\hline № & Name and essence of indicators & $\begin{array}{l}\text { Calculation } \\
\text { formula }\end{array}$ \\
\hline 2.1 . & \multicolumn{2}{|l|}{$\begin{array}{l}\text { Indicators of the economic subsystem reflect the concentration, manufacturability and diversification of an } \\
\text { enterprise in the telecommunications services market, taking into account funds }\left(\mathrm{C}_{\mathrm{e}}^{\prime \prime}\right) \text { that were spent on } \\
\text { measures for economic development }\end{array}$} \\
\hline 2.1 .1 & $\begin{array}{l}\text { The concentration of an enterprise on the telecommunications services market determines the change } \\
\text { in the market share occupied by a telecommunications company }\left(\Delta \mathrm{K}_{\mathrm{mc}}\right)\end{array}$ & $D_{1.1}^{\prime \prime}=\frac{\Delta K_{m c}}{C_{e}^{\prime \prime}}$ \\
\hline 2.1 .2 & $\begin{array}{l}\text { Manufacturability of the enterprise, change in the provision of the latest technologies, taking } \\
\text { into account the available technologies in the market where the company operates }\left(\Delta \mathrm{K}_{\mathrm{mc}}\right)\end{array}$ & $D_{1.2}^{\prime \prime}=\frac{\Delta K_{a}}{C_{e}^{\prime \prime}}$ \\
\hline 2.1 .3 & $\begin{array}{l}\text { Diversification of investment activities, change in the volume of external investments } \\
\text { (participation in capital, shares of other enterprises) of a telecommunications company }\left(\Delta \mathrm{K}_{\text {in }}\right)\end{array}$ & $D_{1.3}^{\prime \prime}=\frac{\Delta K_{i n}}{C_{e}^{\prime \prime}}$ \\
\hline 2.2 . & \multicolumn{2}{|c|}{$\begin{array}{l}\text { The indicators of the social subsystem reflect the level of customer satisfaction with telecommunications } \\
\text { services, the degree of impact-investment, the compliance of the wages of the company's employees with market } \\
\text { conditions, taking into account the funds }\left(\mathrm{C}_{\mathrm{s}}\right) \text { that were spent on external measures for social development }\end{array}$} \\
\hline 2.2 .1 & $\begin{array}{l}\text { Satisfaction of consumers with telecommunication services is characterized by a change in the } \\
\text { saturation of consumers of a telecommunications enterprise }\left(\Delta \mathrm{K}_{\mathrm{st}}\right)\end{array}$ & $D_{2.1}^{\prime \prime}=\frac{\Delta K_{s t}}{C_{s}^{\prime \prime}}$ \\
\hline 2.2 .2 & $\begin{array}{l}\text { The degree of impact-investment of a telecommunications enterprise has a change in the } \\
\text { volume of social investment and charitable activities of the enterprise }\left(\Delta \mathrm{K}_{\mathrm{ii}}\right)\end{array}$ & $D_{2.2}^{\prime \prime}=\frac{\Delta K_{i i}}{C_{s}^{\prime \prime}}$ \\
\hline 2.2 .3 & $\begin{array}{l}\text { The compliance of the wages of employees reflects the change in the level of wages of employees } \\
\text { in relation to the average wages in the communications and informatization sphere }\left(\Delta \mathrm{K}_{\mathrm{p}}\right)\end{array}$ & $\mathrm{D}_{2.3}^{\prime \prime}=\frac{\Delta \mathrm{K}_{\mathrm{p}}}{\mathrm{C}_{\mathrm{s}}^{\prime \prime}}$ \\
\hline 2.3 . & \multicolumn{2}{|c|}{$\begin{array}{l}\text { The indicators of the ecological subsystem reflect the recoverability of damaged ecosystems, the } \\
\text { environmental friendliness of the technologies used and the volume of environmental investments, taking into } \\
\text { account the funds }\left(\mathrm{C}^{\prime \prime}{ }_{\text {ec }}\right) \text { that were spent on external measures for environmental development }\end{array}$} \\
\hline 2.3 .1 & $\begin{array}{l}\text { Recoverability indicates a change in the level of restoration of damaged ecosys } \\
\text { telecommunications company in the course of its activities }\left(\Delta \mathrm{K}_{\mathrm{er}}\right)\end{array}$ & $\mathrm{D}_{3.1}^{\prime \prime}=\frac{\Delta \mathrm{K}_{\mathrm{er}}}{\mathrm{C}_{\mathrm{ec}}^{\prime \prime}}$ \\
\hline 2.3.2. & $\begin{array}{l}\text { Environmental friendliness of the technologies used in the provision of telecommunication } \\
\text { services, change of the telecommunications company }\left(\Delta \mathrm{K}_{\mathrm{et}}\right)\end{array}$ & $\mathrm{D}_{3.2}^{\prime \prime}=\frac{\Delta \mathrm{K}_{\mathrm{et}}}{\mathrm{C}_{\mathrm{ec}}^{\prime \prime}}$ \\
\hline 2.3.3. & $\begin{array}{l}\text { The environmental investment of a telecommunications enterprise is characterized by a change } \\
\text { in the volume of environmental investments }\left(\Delta \mathrm{K}_{\mathrm{ei}}\right)\end{array}$ & $\mathrm{D}_{3.3}^{\prime \prime}=\frac{\Delta \mathrm{K}_{\mathrm{ei}}}{\mathrm{C}_{\mathrm{ec}}^{\prime \prime}}$ \\
\hline 2.4 . & \multicolumn{2}{|c|}{$\begin{array}{l}\text { The indicators of the institutional subsystem reflect the degree of joint activities, public-private partnerships and the } \\
\text { image of a telecommunications enterprise, taking into account the funds }\left(\mathrm{C}^{\prime \prime}{ }_{i n}\right) \text { that were spent on external measures } \\
\text { for institutional development }\end{array}$} \\
\hline 2.4 .1 & $\begin{array}{l}\text { Joint activity of a telecommunications enterprise is determined by changes in joint activities } \\
\text { with stakeholders }\left(\Delta \mathrm{K}_{\mathrm{ca}}\right)\end{array}$ & $\mathrm{D}_{4.1}^{\prime \prime}=\frac{\Delta \mathrm{K}_{\mathrm{ca}}}{\mathrm{C}_{\mathrm{in}}^{\prime \prime}}$. \\
\hline 2.4 .2 & $\begin{array}{l}\text { The involvement of an enterprise in the process of public-private partnership reflects the } \\
\text { change in the degree of participation of the enterprise in the implementation of government } \\
\text { programs }\left(\Delta \mathrm{K}_{\mathrm{ppp}}\right)\end{array}$ & $\mathrm{D}_{4.2}^{\prime \prime}=\frac{\Delta \mathrm{K}_{\mathrm{ppp}}}{\mathrm{C}_{\mathrm{in}}^{\prime \prime}}$. \\
\hline 2.4 .3 & $\begin{array}{l}\text { The image of a telecommunications enterprise shows a change in the attitude of consumers to } \\
\text { the enterprise }\left(\Delta \mathrm{K}_{\mathrm{m}}\right)\end{array}$ & $\mathrm{D}_{4.3}^{\prime \prime}=\frac{\Delta \mathrm{K}_{\mathrm{m}}}{\mathrm{C}_{\mathrm{in}}^{\prime \prime}}$ \\
\hline
\end{tabular}

Source: constructed by the authors. 
corrective coefficient for assessing the TE business value.

The basis for determining the effectiveness of the BD TE is based on indicators of external and internal development, which contain indicators of economic, social, environmental and institutional subsystems, as a result, they allow to determine the value of the efficiency multiplier of BD TE. The indicators of internal (Table 1) and external (Table 2) development of a telecommunications enterprise characterize the changes taking place at the enterprise of an economic, social, environmental and institutional nature, taking into account the corresponding investment in these subsystems.

The value of the balanced development efficiency multiplier, which is used as a correcting coefficient in assessing the value of a telecommunications enterprise, is calculated by the formula (1).

$$
M=\sqrt[n]{\prod_{i=1}^{n}\left(\sum_{j=1}^{m} \frac{\Delta D_{i j}}{C_{i}}\right)^{\frac{1}{m}}}
$$

where M - multiplier of the $i$ subsystem of indicators of the $\mathrm{j}$ type of BD indicators;

$\Delta \mathrm{D}_{\mathrm{ij}}=\mathrm{D}_{\mathrm{ij}(t)}-\mathrm{D}_{\mathrm{ij}(t-1)}-$ factor affecting the efficiency of a telecommunications enterprise;

$\mathrm{C}_{\mathrm{i}}$ - costs for development activities.

Taking into account the current state of development of telecommunications companies, the authors have identified four levels of assessment of BD TE based on the use of the method of modeling real processes using scales. Since the value of the balanced development efficiency multiplier can range from 0 to 2.0 , it is expedient to conditionally divide the range of values into four parts:

0.00-0.37 - unbalanced development - the assessment indicates the inharmonious development of a telecommunications enterprise with an imbalance in the economic, environmental and social subsystems that require immediate solutions;

0.38-0.67 - economically sustainable development - the assessment indicates economically harmonious development, the sufficiency of internal and external resources necessary to ensure balanced development;

0.68-0.91 - economically and socially sustainable development - the assessment indicates the sustainable development of economic and social subsystems, the sufficiency of internal and external resources necessary to ensure harmoniously balanced development;

0.92-2.00 - balanced development - the assessment indicates a harmonized, balanced development of economic, social and environmental activities, which is characterized by economic growth, social stability and ecological balance. Enterprises with such an assessment are actively pursuing internal and external social investment, pursuing environmental and energy saving policies, and the like

The use of such a scale helps to assess the effectiveness of the balanced development of a telecommunications enterprise not only as balanced and unbalanced, but to assess the multi-level one, allowing to assess the balance of economic, social and environmental activities of telecommunications enterprises, which can be the basis for the development of measures aimed at eliminating shortcomings in the enterprise's activities to balance the economic, social, environmental activities.

The multiplier should be applied as a ratio to the valuation of the telecommunications business (for example, using methods of capitalizing earnings, net assets (at fair value) and discounted cash flows, etc.). Taking into account the value of the balanced development efficiency multiplier, the business value of telecommunications enterprises can increase or decrease. The multiplakator demonstrates the influence of harmonious balanced development on business value and emergence, that is, the formation of additional qualities in a telecommunications enterprise that are not inherent in its elements and which cannot be reduced to their simple sum. The system being created receives new qualitative characteristics that differ significantly from those that have its elements. That is, the latter serve as a prerequisite for the creation of its new qualities of a telecommunications enterprise, which also leads to globalization and informatization.

After completing the assessment of the effectiveness of the BD TE, it is necessary to identify problem areas in balanced development in order to form a triune strategy for balanced development aimed at determining the directions for further development and their implementation, predicting the future state of the TE, as well as determining an effective methodological toolkit for stimulating the $\mathrm{BD}$ TE, consisting of the relevant principles, tools, forms of influence, methods and means.

The process of stimulating the provision of $\mathrm{BD} T E$ should be based on such principles as:

1) differentiation of marketing efforts - when consuming telecommunication services, consumers have different reactions to TE offers, it causes keeping records of these differences and the orientation of service providers to specific groups of consumers is one of the conditions for the functioning of TE of the ICT market;

2) dynamic correspondence - considers maintaining a balance between the demand for services of the ICT market and the needs of the ICT market itself in dynamics; 
3) consistency - considers the totality of information sources that can characterize the consumer demand of telecommunications services. The main ones include: statistical information, data from ministries, information obtained as a result of surveys; at the same time, the offer of telecommunication services of the enterprise should be formed not from the current interests of consumers and TE requests, but according to forecasts based on researches and analysis of trends;

4) overcoming social inertia - preventing the formation of stakeholders' own opinion on social responsibility under the influence of the negative opinion of the immediate environment, pleasure at least the minimum needs of all individuals in order to provide an opportunity to realize their hopes for a prosperous life;

5) continuity - TE in order to adapt the offer of telecommunications services and conduct a socially and environmentally responsible business, it is necessary to constantly dynamically develop economic, environmental and social activities, taking into account the constantly changing consumer preferences, the needs of the country's economy in ICT services;

7) environmental orientation - the formation and development of eco-culture, the approval of social and moral norms and values and the education of the environmental outlook of consumers of telecommunications services by promoting a careful attitude to the use of natural resources and adding to the solution of environmental problems through the media, public events;

5) limitedness - observance of rationality in the consumption of economic, energy, labor, technological and other resources during operation, as well as awareness of their responsibility for the consumption, production and distribution of resources;

8) complexity - the process of ensuring the BD TE should simultaneously cover the implementation of both economic, social and environmental development goals of the enterprise, take into account all possible factors and conditions that may affect the quality of development.

When stimulating the provision of $\mathrm{BD} T E$, according to the authors, two forms can be used: active or passive impact on balanced development. The passive form is characterized by the fact that the free funds of the enterprise are directed to solving only production goals, covering current costs as a result of which the level of social responsibility of the TE decreases and the equilibrium is lost. The active form is distinguished by the fact that the funds of the enterprise are used not only to solve production needs, but also to meet the primary internal (personnel) and external (stakeholders) social and environmental needs.
At the same time, it is advisable to use various methods of stimulating BD TE:

- management of the creation of advisory committees, centers, etc. in the implementation of the provisions of the concept of sustainable development, coordination and specialization of individual links of the enterprise;

- control - observation, examination and experiment; comparison of the results achieved with the established norms, standards, reference values; use of advanced control methods, etc.;

- analysis - qualitative and quantitative analysis of business processes, taking into account the provisions of the concept of sustainable development and economic, social and environmental activities of the TE;

- forecasting - forecasting the level of financial stability, social and environmental responsibility based on the use of heuristic and economic-mathematical methods, taking into account environmental factors;

- monitoring - using a process approach to monitoring the effectiveness of BD TE.

The means of stimulating the balanced development of telecommunications companies can be:

1. Improvement of legislative acts on the protection of intellectual property and regulation of the ICT market to ensure the availability, opportunity and profitability of consumers of products and services of the ICT market for the social and environmental responsibility of telecommunications companies.

2. Improving the tax system by introducing simplified licensing regimes, increasing the number of available market sectors, reducing regulatory obligations, tax benefits and incentives, regressive interest rates on taxation objects of the TE.

3. Increasing the powers and functions of institutions for quality control of products and services provided in the ICT market by telecommunications enterprises. As well as increasing control by the relevant institutions on the state of social and environmental responsibility of the TE to society.

4. Provision of high-quality labor resources of TE with the help of a modern education system, health care, organization of effective social security.

The tools to stimulate the BD TE are:

1) the economic policy of TE, should take into account the requests of all consumers about the need to provide innovative telecommunication services, price differentiation for the volume and structure of services, their distribution among consumers for cities and rural areas, promotion of ICT services should intensify in the conditions of insufficient consumer awareness of new services in the ICT market (with the possession of promotion tools, it can increase the attractiveness of individual services of the providers of 
these services, regulating their volume and structure, stimulating demand), material support can reduce uncertainty in the further development of TE in the ICT market by introducing new funding channels for research and development;

2) the social policy of the TE should be aimed at both the personnel and the consumer of the ICT market services, which are an important tool to stimulate demand, especially its behavior, communication style, degree of interest in interacting with consumers, etc.; on the formation of a developed social infrastructure of the TE; for sponsorship, charity for the provision of services of hospitals, orphanages, etc.;

3 ) the environmental policy of the TE must comply with the market requirements for the provision of competitive services and the use of equipment that are safe for others when consuming telecommunication services, can be achieved only on the basis of the development, modernization of production and increasing the level of its environmental safety; the policy should be aimed at ensuring the effective use and reproduction of natural resources, environmental protection, with full awareness of the importance and necessity of using technology and the introduction of technologies with minimal impact on the environment.

\section{Conclusions}

The presented mechanism for assessing the effectiveness of balanced development is an integral system of analytical, evaluative and resulting blocks, it allows to determine, on the basis of the multiplier, the effectiveness of the economic, social and environmental activities of a TE in the context of increasing integration trends in the world economy, the complication of multi-level relationships between the subjects of the global economic system and the emergence of new contradictions between them. The proposed mechanism for assessing the effectiveness of the BD TE will allow tracking the dynamics of the performance of the enterprise based on the study of economic, environmental and social development subsystems, as well as making a comparison with other enterprises in the sphere on the national and world markets to achieve economic growth, social stability and ecological balance. The system of indicators has been formed that takes into account the factors of the external and internal environment, which determine the indicators of the economic, social, environmental and institutional subsystem. It is proposed to use the balanced development efficiency multiplier as a correcting coefficient when assessing the value of telecommunications enterprise business, the value of which fluctuates within the specified limits. Ranking the assessment of the level of balanced development in accordance with the scale and determine the zones of the efficiency multiplier in accordance with the developed scale, makes it possible to form a three-dimensional strategy of sustainable development. Stimulating the provision of balanced development of a telecommunications enterprise is based on the principles of differentiating marketing efforts, dynamic compliance, consistency, overcoming social inertia, continuity, environmental focus, limitation and complexity. In this case, one should use an active or passive form with the use of appropriate levers, tools, methods and means.

\section{Acknowledgements}

Participation in the conference was funded by European Regional Development Fund (ERDF), Measure 1.1.1.5 "Support to international cooperation projects in research and innovation of RTU". Project No. 1.1.1.5/18/I/008.

\section{References}

Entner, R., \& Lewin, D. (2010). The Impact of the US Wireless Telecom Industry on the US Economy. Boston, MA 02108: Ovum; London, England N1 8JX: Indepen Diespeker Wharf.

Granaturov, V.M., \& Vorobienko, S.P. (2009). Analysis of the competitiveness of telecommunication services. Kiev: Education of Ukraine. (in Ukrainian).

Granaturov, V.M. (2009). Analysis of the competitiveness of telecommunications services. Kiev: Education of Ukraine. (in Ukrainian).

Demianchuk, M., Bezpartochnyi, M., Filipishyna, L., \& Živitere, M. (2021). The model of achieving a balanced balance between economic efficiency and ecological-social responsibility of digitalized enterprise. Journal of Optimization in Industrial Engineering. 14, 1, 63-70. DOI: 10.22094/JOIE.2020.677817.

Demianchuk, M. (2020). The use of neural networks in the activities and development of a digitized enterprise while achieving balanced development. Investytsiyi: praktyka ta dosvid. 4, 11-17. DOI: 10.32702/23066814.2020.4.11. (in Ukrainian).

Heeks, R. (2010). Do Information Technologies (ICTs) Contribute To Development. Journal of International Development. 22, 625-640.

Iscan, E. (2012). The impact of information and communication technology on economic growth: Turkish case. International journal of ebusiness and egovernment studies. 4, 2, 17-26.

Katz, R. (2012). The Impact of Broadband on the Economy: Research to Date and Policy Issues. Geneva, Switzerland CH-1211: International Telecommunication Union. 
Khrushch, N.A., \& Koran, A.S. (2011). Marketing strategies in the field of telecommunications. In S.V. Kovalchuk (Ed.), Marketing technologies in conditions of innovative economic development (pp. 53-58). Khmelnitsky, Polygraph-2. (in Ukrainian).

Kniazieva, E., \& Doysan-Korovenkova, N. (2015). Reorientation of a Telecommunications company on the sustainable type of development. Economics. Management. Business. 2, 117-122. Retrieved November 21, 2020, from http://journals.dut.edu.ua/index.php/emb/article/view/453. (in Ukrainian).

Kniazieva, E., \& Kalugina, N. (2015). Improvement of marketing communication channels of the telecommunication enterprise. Economics. Management. Business. 2, 21-26. Retrieved November 21, 2020, from http://journals.dut.edu.ua/index.php/emb/article/view/438. (in Ukrainian).

Maslii, N., Zakharchenko, N., \& Kostolonova, L. (2017). Peculiarities of the international outsourcing services: Ukrainian perspectives. Baltic Journal of Economic Studies. 3, 2, 86-92.

Orlov, V.M., Politova, I.V., \& Pavlyuk, V.I. (2011). Components of ensuring effective regulation of the modern services market. Bulletin of Chernivtsi Trade and Economics Institute. II (42), 2, 1, 200-214. (in Ukrainian),

Redkin, A.S., \& Koval, V.V. (2007). Research of the process of updating information assets of enterprises in the field of telecommunications: International Conference Quality Strategy in Industry and Education, June 1-8, 2007 (pp. 623-626). Varna, Bulgaria. Ukraine: Fortune. (in Ukrainian).

Souter, D., Scott, N., Garforth, C., Jain, R., Mascarenhas, O., \& McKemey, K. (2005). The Economic Impact of Telecommunications on Rural Livelihoods and Poverty Reduction: A study of rural communities in India (Gujarat), Mozambique and Tanzania. Commonwealth Telecommunications Organisation for UK Department for International Development.

Steklov, V.K., Kostik, B.Ya., \& Berkman, L.N. (2005). Control systems in telecommunications. Kiev: Tekhnika. (in Ukrainian).

Striy, L.A., Zaharchenko, L.A., \& Golubev, A.K. (2014). Market mechanisms and structures of the economics of infocommunication services. Economics: time realities. 1 (11), 134-141. Retrieved November 21, 2020, from https://economics.opu.ua/files/archive/2014/No1/134-141.pdf. (in Ukrainian).

Vorobienko, P.P., \& Granaturov, V.M. (2011). Problems of using the laws of ICT influence on the country's economic development. Economy of Ukraine. 8, 26-32. (in Ukrainian). 